\title{
A Study on the Physiological Profiles and Performance Characteristics of Modern Pentathletes
}

\author{
Jae-Ryang Yoon \\ Department of Physical Education, Korea National Sport University, Seoul, 05541, South Korea
}

Received December 19, 2021; Revised January 21, 2022; Accepted February 20, 2022

\begin{abstract}
Cite This Paper in the following Citation Styles
(a): [1] Jae-Ryang Yoon, "A Study on the Physiological Profiles and Performance Characteristics of Modern Pentathletes," International Journal of Human Movement and Sports Sciences, Vol. 10, No. 1, pp. 104 - 111, 2022. DOI: 10.13189/saj.2022.100115.
\end{abstract}

(b): Jae-Ryang Yoon (2022). A Study on the Physiological Profiles and Performance Characteristics of Modern Pentathletes. International Journal of Human Movement and Sports Sciences, 10(1), 104 - 111. DOI: 10.13189/saj.2022.100115.

Copyright $\bigcirc 2022$ by authors, all rights reserved. Authors agree that this article remains permanently open access under the terms of the Creative Commons Attribution License 4.0 International License

\begin{abstract}
Modern pentathlon is characterized by the possible direct effects on performance of physical characteristics, fitness level, and record management and therefore, obtaining information about the fitness level and records can be an important factor in improving performance among athletes. To examine the specificity of anthropometrics, physiology, and performance among modern pentathlon athletes, it is necessary to examine and analyze many factors for performance and few researchers have measured or analyzed modern pentathletes. This study aimed to analyze anthropometric data of elite modern pentathalon athletes through a literature review and determine the physical characteristics for better performance, examine cardiorespiratory functions directly connected with the performance in sport shooting-running. The literature review found that maximal heart rate (HRmax) ranged from $184.10 \mathrm{bpm}$ to $197.89 \mathrm{bpm}$, maximal voluntary ventilation (VEmax) from 151.7 $\mathrm{L} / \mathrm{min}$ to $163.05 \mathrm{~L} / \mathrm{min}$, and maximal oxygen uptake $\left(\mathrm{VO}_{2}\right.$ $\max$ ) from $54.4 \mathrm{ml} / \mathrm{kg} / \mathrm{min}$ to $75.97 \mathrm{ml} / \mathrm{kg} / \mathrm{min}$. For the anaerobic threshold (AT) level, oxygen uptake $\left(\mathrm{VO}_{2}\right)$ ranged from $53.72 \mathrm{ml} / \mathrm{kg} / \mathrm{min}\left(82.6 \% \mathrm{VO}_{2} \max \right)$ to 63.65 $\mathrm{ml} / \mathrm{kg} / \mathrm{min}\left(84.4 \% \mathrm{VO}_{2} \max \right)$, heart rate from $169 \mathrm{bpm}$ to $182 \mathrm{bpm}$, and blood lactate concentration from $10.64 \mathrm{mM}$ to $17.20 \mathrm{mM}$. Therefore, it is also necessary to develop an effective interval training method for improving anaerobic threshold, cardiorespiratory endurance, and lactate tolerance. Further research is needed to identify effective training for improving cardiorespiratory endurance, the AT level, and lactate tolerance rather than the physical characteristics.
\end{abstract}

Keywords Modern Pentathlete, Body Composition, Cardioresipatory Function, Laser-Run

\section{Introduction}

Modern pentathlon consists of five events, namely epee, swimming (freestyle $200 \mathrm{~m}$ ), equestrian jumping, and a new combined event (five sessions of shooting $10 \mathrm{~m}$ * pistol shooting + four repetitions of running $800 \mathrm{~m}$ ), with the records in the five events added up to determine the winner [6, 23, 33, 41]. Specifically, control, power, concentration, adjustment, and coordination are important for equestrian jumping; agility, power, endurance, responsiveness, and determination are important for epee; power, flexibility, and cardiorespiratory endurance are important for swimming; and fitness factors such as judgment, speed, general endurance, concentration, composure, cardiorespiratory fitness, and muscular endurance are important for the new combined event (laser-run) [23, 35].

Modern pentathlon is characterized by the possible direct effects on performance of physical characteristics, fitness level, and record management and by ranking based on converted scores for the fitness level and records in each event; therefore, obtaining information about the fitness level and records can be an important factor in improving performance among athletes [30]. It is necessary to collect detailed data regarding the determinants of performance comprehensively and 
systematically [38].

While some studies have been conducted on modern pentathlon by determining the effects of training methods on swimming and running performance $[20,29]$ and the effects of bio-feedback training on heart beat in pistol shooting, there are still limitations in determining the association between events and performance [41]. In modern pentathlon, a laser-run (new combined event) has similar characteristics to biathlon, an event of winter sports, and the sum of scores for the two events of track and pistol shooting rather than the records in both events play a crucial role in ranking [41]. A few studies on multi-sport events, including biathlon and triathlon, confirm that the order in performing these events ultimately exerts a great impact on performance; and this implies the need to differentiate and characterize the events, while taking the personal characteristics of athletes into account $[32,41]$.

In most sports, a successful condition for athletes depends on their physical capabilities; the higher the level of training experiences and performance they have, the lower the level of physical capabilities they may show in the same event and training. However, little research has been conducted on the properties of body composition in modern pentathlon athletes as well as on the references for the system of energy supply. The performance in modern pentathlon can depend on the laser-run, even with five events. Moreover, useful indicators to determine performance in the recent laser-run are heart beat control to meet the level of speed with the variation in instantaneous exercise intensity and muscle strength and cardiorespiratory endurance, which are principal factors for performance. [32, 41]. The highest score in the laser-run depends on whether the athlete made the best use of his/her $\mathrm{VO}_{2} \max$ capabilities [33]. Still, little research has been conducted on the cardiorespiratory fitness or energy metabolic demands of modern pentathalon athletes.

This study aimed to analyze anthropometric data of elite modern pentathalon athletes through a literature review and determine the physical characteristics for better performance, examine cardiorespiratory functions directly connected with the performance in sport shooting-running (laser-run) based on pistol shooting scores and track records, and investigate the characteristics of the performance in the laser-run, which determines modern pentathlon performance.

\section{Materials and Methods}

\subsection{Physique and Body Composition of Modern Pentathlon Athletes}

To examine the specificity of anthropometrics, physiology, and performance among modern pentathlon athletes, it is necessary to examine and analyze many factors for performance and few researchers have measured or analyzed these variables.

The results of the literature review of the characteristics of physique and body composition of male and female elite modern pentathlon athletes are summarized in Table 1. For the physical characteristics of modern pentathletes, weight ranged from $68.85 \mathrm{~kg}$ to $70.32 \mathrm{~kg}$ for male adults $[21,40-41]$ and was approximately $61 \mathrm{~kg}$ for female adults [35]. Height ranged from $169 \mathrm{~cm}$ to $178 \mathrm{~cm}$ for male adults $[21,33,35,40-41]$ and from $161 \mathrm{~cm}$ to 168 $\mathrm{cm}$ for female adults $[33,35]$. The body mass index (BMI) ranged from 20.38 to 22.80 for male adults $[33-35,41]$ and from 20.19 to 24.30 for female adults $[6,33,35]$. The body fat percentage (\%body fat) ranged from $10.77 \%$ to $15.5 \%$ for male adults $[21,33,35]$ and from $16.0 \%$ to $28.4 \%$ for female adults [33, 35]. Research on the anthropometrics of male collegiate modern pentathlon athletes found that muscle mass, LBM, body fat, and BMI-33.8 $( \pm 5.1) \mathrm{kg}, 59.5( \pm 8.2) \mathrm{kg}, 13.4( \pm 5.3) \%$, and $21.8( \pm 0.9)$, respectively — were at similar levels to those in this study. A recent study showed that age, weight, height, and BMI were $21.7( \pm 3.1)$ years, $75.9( \pm 9.5) \mathrm{kg}$, $182.6( \pm 6.1) \mathrm{cm}$, and $22.7( \pm 2.3) \mathrm{kg} / \mathrm{m}^{2}$, respectively, for Polish (Warsaw in Poland) elite male modern pentathlon athletes [15], demonstrating that they were at significantly higher levels of height and weight and at similar levels of BMI compared with the findings of the literature review. 
Table 1. Main charateristics of modern pentathlon athletes according to gender

\begin{tabular}{|c|c|c|c|c|c|}
\hline \multirow{2}{*}{ Variables } & \multicolumn{2}{|c|}{ Male } & \multicolumn{2}{|c|}{ Female } & \multirow{2}{*}{ Reference } \\
\hline & Pubescent & Post-pubescent & Pubescent & Post-pubescent & \\
\hline $\begin{array}{l}\text { Body } \\
\text { weight } \\
(\mathrm{kg})\end{array}$ & $\begin{array}{c}- \\
58.52( \pm 8.69)\end{array}$ & $\begin{array}{c}- \\
- \\
68.85( \pm 1.91) \\
66.70( \pm 4.8) \\
70.32( \pm 3.42)\end{array}$ & $\begin{array}{c}- \\
52.60( \pm 6.69)\end{array}$ & $\begin{array}{c}61.00( \pm 5.3) \\
-\end{array}$ & $\begin{array}{c}\text { Loureiro et al. [35], } \\
\text { Kim et al. [21], } \\
\text { Yoon et al. [41], } \\
\text { Yoon et al. [40] }\end{array}$ \\
\hline $\begin{array}{l}\text { Height } \\
(\mathrm{cm})\end{array}$ & $\begin{array}{c}- \\
163.40( \pm 10.3) \\
-\end{array}$ & $\begin{array}{c}- \\
175.90( \pm 7.4) \\
169.00( \pm 7.0) \\
176.0( \pm 4.02) \\
176.0( \pm 5.2) \\
178.95(2.33)\end{array}$ & $\begin{array}{c}- \\
155.50( \pm 10.7) \\
-\end{array}$ & $\begin{array}{c}168.1( \pm 5.4) \\
162.60( \pm 3.5) \\
161.00( \pm 6.0)\end{array}$ & $\begin{array}{c}\text { Coutinho et al. [33], } \\
\text { Loureiro et al. [35], } \\
\text { Kim et al. [21], } \\
\text { Yoon et al. [41], } \\
\text { Yoon et al. [40] }\end{array}$ \\
\hline $\begin{array}{c}\mathrm{BMI} \\
\left(\mathrm{kg} / \mathrm{m}^{2}\right)\end{array}$ & $\begin{array}{c}- \\
- \\
21.68( \pm 3.2)\end{array}$ & $\begin{array}{c}- \\
20.38( \pm 1.66) \\
22.80( \pm 1.9) \\
22.18( \pm 0.9) \\
22.18( \pm 0.59)\end{array}$ & $\begin{array}{c}- \\
- \\
20.10( \pm 2.6)\end{array}$ & $\begin{array}{c}21.60( \pm 1.4) \\
20.19( \pm 1.44) \\
24.30( \pm 2.4)\end{array}$ & $\begin{array}{l}\text { Loureiro et al. [35], } \\
\text { Coutinho et al. [33], } \\
\text { Yoon et al. [40], } \\
\text { Lim et al. [29] }\end{array}$ \\
\hline $\begin{array}{c}\text { Body fat } \\
(\%)\end{array}$ & $\begin{array}{c}- \\
20.40( \pm 8.3) \\
-\end{array}$ & $\begin{array}{c}- \\
15.50( \pm 6.4) \\
14.24( \pm 1.97) \\
10.77( \pm 0.65)\end{array}$ & $\begin{array}{c}- \\
23.80( \pm 6.8) \\
-\end{array}$ & $\begin{array}{c}16.00( \pm 2.4) \\
28.40( \pm 1.2) \\
23.66( \pm 7.33)\end{array}$ & $\begin{array}{c}\text { Coutinho et al. [33], } \\
\text { Loureiro et al. [35], } \\
\text { Kim et al. [21] }\end{array}$ \\
\hline
\end{tabular}

Table 2. Summary of anthropometric data in different sports event besides MP*

\begin{tabular}{|c|c|c|c|c|c|c|c|}
\hline Items & Age & $\begin{array}{l}\text { Height } \\
\text { (cm) }\end{array}$ & $\begin{array}{l}\text { Weight } \\
\text { (kg) }\end{array}$ & $\begin{array}{c}\text { BMI } \\
\left(\mathrm{kg} / \mathrm{m}^{2}\right)\end{array}$ & $\begin{array}{c}\text { Body fat } \\
(\%)\end{array}$ & LBM & Reference \\
\hline $\begin{array}{c}\text { Biathlon } \\
\text { pentathletes }\end{array}$ & $\begin{array}{l}21.4 \pm 2.1 \\
19.6 \pm 1.5\end{array}$ & $\begin{array}{l}181.1 \pm 4.7 \\
184.7 \pm 3.2\end{array}$ & $\begin{array}{l}76.5 \pm 4.8 \\
73.1 \pm 4.1\end{array}$ & $\begin{array}{c}23.5 \pm 1.3 \\
-\end{array}$ & $\begin{array}{c}- \\
8.8 \pm 0.7\end{array}$ & & $\begin{array}{l}\text { Luchsinger et al. [36], } \\
\text { Cech et al. [39] }\end{array}$ \\
\hline Fencing & $\begin{array}{l}21.5 \pm 2.6 \\
22.3 \pm 4.5 \\
23.3 \pm 2.8\end{array}$ & $\begin{array}{l}175.2 \pm 6.1 \\
181.0 \pm 5.0 \\
180.8 \pm 5.4\end{array}$ & $\begin{array}{c}71.1 \pm 15.0 \\
76.6 \pm 9.3 \\
79.0 \pm 7.42\end{array}$ & $\begin{array}{c}23.5 \pm 4.5 \\
23.4 \\
24.2 \pm 2.1\end{array}$ & $\begin{array}{c}13.9 \pm 5.9 \\
- \\
15.7 \pm 2.7\end{array}$ & & $\begin{array}{c}\text { Ghloum \& Hajji [18], } \\
\text { Gutierrez-Davila et al. [12], } \\
\text { Sterkowicz-Przybycień [17] }\end{array}$ \\
\hline $\begin{array}{l}\text { Shooters } \\
\text { (female) }\end{array}$ & $\begin{array}{c}23.1 \pm 1.8 \\
31.2 \pm 11.2\end{array}$ & $\begin{array}{l}175.3 \pm 4.7 \\
164.0 \pm 0.6\end{array}$ & $\begin{array}{l}78.5 \pm 7.6 \\
66.6 \pm 12.2\end{array}$ & $\begin{array}{l}22.2 \pm 3.7 \\
24.6 \pm 4.3\end{array}$ & $\begin{array}{l}- \\
-\end{array}$ & & $\begin{array}{l}\text { Molla et al. [37], } \\
\text { Mon-López et al. [7] }\end{array}$ \\
\hline $\begin{array}{l}\text { Jockeys } \\
\text { (female) }\end{array}$ & $\begin{array}{c}24.0 \pm 3.1 \\
28.7 \pm 10.1\end{array}$ & $\begin{array}{l}172.0 \pm 5.2 \\
163.4 \pm 7.1\end{array}$ & $\begin{array}{l}63.2 \pm 4.7 \\
55.1 \pm 5.9\end{array}$ & $\begin{array}{c}- \\
20.6 \pm 1.6\end{array}$ & $\begin{array}{l}11.3 \pm 2.2 \\
13.9 \pm 3.5\end{array}$ & & $\begin{array}{l}\text { Wilson et al. [11], } \\
\text { Hitchens et al. [14] }\end{array}$ \\
\hline Swimming & $18.6 \pm 0.7$ & $178.1 \pm 3.1$ & $73.9 \pm 4.3$ & - & $15.4 \pm 2.5$ & & Erica $\mathbf{J}$ et al. [9] \\
\hline $\begin{array}{l}\text { Elite MP } \\
\text { athletes }\end{array}$ & $21.7 \pm 3.1$ & $182.6 \pm 6.1$ & $75.9 \pm 9.5$ & $22.7 \pm 2.3$ & & & Hoffmann et al. [15] \\
\hline $\begin{array}{l}\text { Healthy } \\
\text { non-obese } \\
\text { subjects }\end{array}$ & $\begin{array}{l}44.4 \pm 17.9 \\
51.7 \pm 15.0\end{array}$ & $\begin{array}{l}180.1 \pm 7.2 \\
166.8 \pm 6.5\end{array}$ & $\begin{array}{c}79.2 \pm 10.2 \\
64.4 \pm 8.3\end{array}$ & $\begin{array}{l}24.4 \pm 2.7 \\
23.2 \pm 2.9\end{array}$ & $\begin{array}{l}22.9 \pm 6.4 \\
33.5 \pm 6.7\end{array}$ & $\begin{array}{l}61.2 \pm 6.9 \\
42.6 \pm 3.9\end{array}$ & Armbruster et al. [2] \\
\hline $\begin{array}{c}\text { Elite } \\
\text { European pro } \\
\text { soccer players }\end{array}$ & $24 \pm 3.7$ & $180.5 \pm 5.1$ & $76.7 \pm 5.3$ & & & $67.2 \pm 5.3$ & Owen et al. [1] \\
\hline $\begin{array}{l}\text { K-Pro female } \\
\text { ballet dancer }\end{array}$ & $25.9 \pm 2.8$ & $163.6 \pm 4.2$ & $49.4 \pm 4.4$ & $18.4 \pm 1.0$ & $19.7 \pm 3.0$ & $36.9 \pm 3.3$ & Kim et al. [24] \\
\hline
\end{tabular}

*MP: modern pentathlon athletes

The modern pentathlon was compared with other events (Table 2). There was a report that \%fat mass was usually not more than $10 \%$ (ranging from $4 \%$ to $9 \%$ ) and ranged from $8 \%$ to $16 \%$ during an off-season period for world wrestling champions [43]; the literature review found that it was slightly higher for elite male modern pentathlon athletes, ranging from $10.77 \%$ to $15.50 \%$, which was at a similar level to the off-season level for elite wrestlers. For the physical conditions of European professional soccer players [1], age, height, weight, and
LBM were $24( \pm 3.7)$ years, $180.45( \pm 5.12) \mathrm{cm}, 76.66$ $( \pm 5.34) \mathrm{kg}$, and $67.21( \pm 5.31) \mathrm{kg}$, respectively, which were generally superior to the respective figures for modern pentathletes. For Korean professional female ballet dancers [24], age, height, weight, BMI, \%body fat, and LBM were $25.9( \pm 2.8)$ years, $163.6( \pm 4.2) \mathrm{cm}, 49.4$ $( \pm 4.4) \mathrm{kg}, 18.4( \pm 1.0) \mathrm{kg} / \mathrm{m}^{2}, 19.7( \pm 3.0) \%$, and $36.9( \pm 3.3)$ $\mathrm{kg}$, respectively, which were all inferior to those of female modern pentathletes except for height. Finally, for ordinary German people [2], age, height, weight, BMI, 
LBM, and \%body fat of German men and women were $44.4( \pm 17.9)$ y and $51.7( \pm 15.0)$ years, $180.1( \pm 7.2) \mathrm{cm}$ and $166.8( \pm 6.5) \mathrm{cm}, 24.4( \pm 2.7) \mathrm{kg} / \mathrm{m}^{2}$ and $23.2( \pm 2.9)$ $\mathrm{kg} / \mathrm{m}^{2}, 61.2( \pm 6.9) \mathrm{kg}$ and $42.6( \pm 3.9) \mathrm{kg}$, and $22.9( \pm 6.4) \%$ and $33.5( \pm 6.7) \%$, respectively, which are higher than those of modern pentathletes in every category. Ultimately, \%body fat, BMI, and LBM rather than height and weight are expected to be useful as predictors in that they seem to be more positively correlated with performance for modern pentathletes. This is consistent with the finding that body mass and lean body mass were lowest among endurance and team sport players [45].

\section{Cardiorespiratory Functions of Modern Pentathlon Athletes}

\section{(1) Cardiopulmonary fitness in modern pentathlon athletes}

The results of the literature review of the characteristics of cardiorespiratory fitness of male and female elite modern pentathlon athletes are summarized in Table 3. For the cardiopulmonary fitness of male elite modern pentathletes, maximal heart rate (HRmax) ranged from $184.10 \mathrm{bpm}$ to $197.89 \mathrm{bpm}$ [40-41], maximal voluntary ventilation (VEmax) ranged from $151.7 \mathrm{~L} / \mathrm{min}$ to 163.05 $\mathrm{L} / \min [40]$, and maximal oxygen uptake $\left(\mathrm{VO}_{2} \max \right)$ ranged from $54.4 \mathrm{ml} / \mathrm{kg} / \mathrm{min}$ to $75.97 \mathrm{ml} / \mathrm{kg} / \mathrm{min}[19$, 40-41]. For the anaerobic threshold (AT) level, oxygen uptake $\left(\mathrm{VO}_{2}\right)$ ranged from $53.72 \mathrm{ml} / \mathrm{kg} / \mathrm{min}\left(82.6 \% \mathrm{VO}_{2}\right.$ $\max )$ to $63.65 \mathrm{ml} / \mathrm{kg} / \mathrm{min}\left(84.4 \% \mathrm{VO}_{2} \max \right)$ [41], heart rate ranged from $169 \mathrm{bpm}$ to $182 \mathrm{bpm}$ [41], and blood lactate concentration (BLamax) ranged from $10.64 \mathrm{mM}$ to 17.20 $\mathrm{mM}$ [19]. The Graded Exercise Test (GXT) in modern pentathletes showed that exercise duration ranged from 20:30 to $22: 33[19,41]$.

The modern pentathalon was compared with other events: $\mathrm{VO}_{2} \max$ was $60.8( \pm 9.5) \mathrm{ml} / \mathrm{kg} / \mathrm{min}$ for endurance athletes, $61.4( \pm 4.4) \mathrm{ml} / \mathrm{kg} / \mathrm{min}$ for kaykers, and 61.8
$( \pm 4.0) \mathrm{ml} / \mathrm{kg} / \mathrm{min}$ for caoeists [4]. For sprint and power, it was $52.1( \pm 7.7) \mathrm{ml} / \mathrm{kg} / \mathrm{min}$ for men and $46.1( \pm 7.2)$ $\mathrm{ml} / \mathrm{kg} / \mathrm{min}$ for women [27]. For combat sports, it was 55.6 $( \pm 9.5) \mathrm{ml} / \mathrm{kg} / \mathrm{min}$ for men and $46.4( \pm 5.2) \mathrm{ml} / \mathrm{kg} / \mathrm{min}$ for women [27]. For junior judo athletes, it was 53 to 66 $\mathrm{ml} / \mathrm{kg} / \mathrm{min}$, which is similar to that of junior boxers [27]. Wrestlers reported an average level of 53 to $56 \mathrm{ml} / \mathrm{kg} / \mathrm{min}$ and Korean representative wrestlers reported HRmax, VEmax, $\mathrm{VO}_{2} \max$, AT (\% of $\left.\mathrm{VO}_{2} \max \right)$, BLamax, and exercise duration of $197.5( \pm 8.8) \mathrm{bpm}, 141.56( \pm 21.99)$ $\mathrm{L} / \mathrm{min}, 60.24( \pm 5.13) \mathrm{ml} / \mathrm{kg} / \mathrm{min}, 8.34( \pm 1.71) \mathrm{mM}, 76.55$ $( \pm 2.92) \%$, and $14.43( \pm 1.57)$ min, respectively [43]. Male badminton players showed a $\mathrm{VO}_{2}$ max range of 50-70 $\mathrm{ml} / \mathrm{kg} / \mathrm{min}[10,26]$, and young male and female racquet players recorded $54.9( \pm 6.7) \mathrm{ml} / \mathrm{kg} / \mathrm{min}$ and $44.0( \pm 4.8)$ $\mathrm{ml} / \mathrm{kg} / \mathrm{min}$, respectively [45].

Winning a match in team sports (basketball, field hockey, soccer, etc.) requires better fitness [44]. That is, soccer players reported 56 to $59 \mathrm{ml} / \mathrm{kg} / \mathrm{min}$ [3], volleyball players reported 46.9 to $51.1 \mathrm{ml} / \mathrm{kg} / \mathrm{min} \mathrm{[8],} \mathrm{and}$ basketball players reported $51.3( \pm 5.7) \mathrm{ml} / \mathrm{kg} / \mathrm{min}$ in Greece and Belgium [16, 45]. For endurance players, in particular AT has been used as a determinant of $\mathrm{VO}_{2} \max$ utilization and long-term mobility [10], which is called the blood lactate-based threshold and is an important key variable that determines the submaximal lactate level (VLT) [4]; they reported a usual level of 80 to 85 $\mathrm{ml} / \mathrm{kg} / \mathrm{min}$ [45]. To summarize the findings of the literature review, modern pentathletes had $\% \mathrm{VO}_{2}$ max at AT ranging from 70.21 to $84.4 \%$, which is very similar to that of endurance athletes [45].

The combined event (laser-run) in modern pentathlon is similar to biathlon and the harmony between track $(800 \mathrm{~m} * 4)$ and pistol shooting $(5 * 4)$ plays a crucial role in determining performance [22]. In the laser-run, instantaneous variation in exercise intensity occurs from the very dynamic movements of running followed by static movements of pistol shooting, where heart rate control based on the increase or decrease in speed and accurate shooting motions become important determinants of performance $[22,38]$.

Table 3. Summary of cardiopulmonary functions of modern pentathletes in previous studies

\begin{tabular}{|c|c|c|c|c|c|c|c|c|}
\hline Reference/Variable & $\begin{array}{c}\text { HRmax } \\
\text { (bpm) }\end{array}$ & $\begin{array}{l}\text { VEmax } \\
(L / \min )\end{array}$ & $\begin{array}{c}\mathrm{VO}_{2} \max \\
(\mathrm{ml} / \mathrm{kg} / \mathrm{min})\end{array}$ & $\begin{array}{c}\% \mathrm{VO}_{2} \max \\
\text { on AT }\end{array}$ & $\begin{array}{c}\mathrm{VO}_{2} \\
\text { on AT }\end{array}$ & $\begin{array}{c}\text { HR } \\
\text { on AT }\end{array}$ & $\begin{array}{c}\text { BLamax } \\
\text { (mM) }\end{array}$ & $\begin{array}{l}\text { Exerciseduration } \\
\text { (min:sec) }\end{array}$ \\
\hline $\begin{array}{c}\text { Kim KJ } \\
{[19]}\end{array}$ & & & $\begin{array}{c}69.68 \\
( \pm 4.12)\end{array}$ & $\begin{array}{c}70.21 \\
( \pm 4.90)\end{array}$ & & & $\begin{array}{c}9.34 * \\
( \pm 0.10) \\
10.64 \# \\
( \pm 1.35)\end{array}$ & $\begin{array}{c}20: 33 \\
( \pm 2.53)\end{array}$ \\
\hline $\begin{array}{c}\text { Yoon JR et al. } \\
{[41]}\end{array}$ & $\begin{array}{l}189.00 \\
( \pm 6.77)\end{array}$ & & $\begin{array}{c}75.97 \\
( \pm 4.92)\end{array}$ & 84.4 & $\begin{array}{c}63.65 \\
( \pm 4.12)\end{array}$ & 169 & & $22: 30$ \\
\hline $\begin{array}{c}\text { Yoon JR et al. } \\
{[40] ※}\end{array}$ & $\begin{array}{l}184.10 \\
( \pm 10.9)\end{array}$ & $\begin{array}{c}151.7 \\
( \pm 15.8)\end{array}$ & $\begin{array}{c}54.4 \\
( \pm 4.4)\end{array}$ & & & & & \\
\hline $\begin{array}{c}\text { Kim HS et al. } \\
{[21]}\end{array}$ & & & & & & & $\begin{array}{l}17.20+ \\
( \pm 1.19)\end{array}$ & \\
\hline
\end{tabular}

*after swimming, \#after running, +whole blood, ※after new combined event

@ junior athletes; $\mathrm{a}: \mathrm{ml} / \mathrm{kg} / \mathrm{min}$ 
Table 4. $\mathrm{HR}, \mathrm{VE}, \mathrm{VO}_{2}$ during the four running phases in the new combined event*

\begin{tabular}{|c|c|c|c|c|}
\hline Variables/Runs & $\mathbf{1}(\mathbf{8 0 0 m})$ & $\mathbf{2}$ & $\mathbf{3}$ & $\mathbf{4}$ \\
$\mathbf{( 1 , 6 0 0 m})$ & $1700 m)$ & $180.0( \pm 10.3)$ & $184.1( \pm 10.9)$ \\
\hline $\mathrm{HR}(\mathrm{bpm})$ & $165.9( \pm 11.5)$ & $13.8( \pm 9.8)$ & $139.5( \pm 17.1)$ & $151.7( \pm 15.8)$ \\
\hline $\mathrm{VE}(\mathrm{L} / \mathrm{min})$ & $120.7( \pm 24.3)$ & $135.5( \pm 15.3)$ & $53.8( \pm 3.4)$ & $54.4( \pm 4.4)$ \\
\hline $\begin{array}{c}\mathrm{VO}_{2} \\
(\mathrm{ml} / \mathrm{kg} / \mathrm{min})\end{array}$ & $45.3( \pm 4.5)$ & $55.4( \pm 4.3)$ & \\
\hline
\end{tabular}

*J.R.Yoon et al. (2017), Analysis of physiological parameters for new combined event in modern pentathletes [41].

\section{(2) Cardiorespiratory functions of modern pentathletes in previous studies}

Previous research of elite modern pentathletes [41] showed variation in $800 \mathrm{~m}$ running time, the heart rate (HR) in each section, ventilation equivalent (VE), and $\mathrm{VO}_{2}$ during the laser-run (Table 4). This research found that HR and VE reflected exercise intensity, which became higher in Sections 3 and 4 than in Sections 1 and 2 , and $\mathrm{VO}_{2}$ was higher in Sections 4,3 , and 2 than in Section 1 . There was a need to keep the $\mathrm{VO}_{2}$ level close to that of maximal oxygen uptake when a slight delay occurs in the shift from track to pistol shooting in the laser-run [31]. This inter-section variation demonstrates the need to control the heart rate stably in pursuit of accurate shooting because the laser-run is characterized by a higher heart rate with fast running at the early stage, making shooting difficult, as found in previous research $[5,28]$. In short, competition with world-class athletes requires consideration of the importance of interval training to improve endurance and lactate tolerance.

\section{(3) Performance characteristics of modern pentathlon athletes}

In modern pentathlon, running scores were separated from pistol shooting scores in the new combined event (laser-run); and a comparison of the total scores, running (800 $\mathrm{m}^{*}$ ) time, running speed, total shooting time, hit rate, and transition time is provided in Table 5. LeMeur et al. [31] showed that the top, middle, and bottom groups had running times of $551 \mathrm{~s}, 549 \mathrm{~s}$, and $564 \mathrm{~s}$, respectively, and running speed of $18.2 \mathrm{~km} / \mathrm{h}, 18.2 \mathrm{~km} / \mathrm{h}$, and 17.7 $\mathrm{km} / \mathrm{h}$, respectively, with no significant difference. In contrast, total shooting time and hit rate showed significant differences because running speed and transition to pistol shooting were not remarkably differentiated among the groups. This indicates that total pistol shooting time is a primary differentiation factor for exercise performance capabilities: the top group had a shorter total shooting time of $23 \mathrm{~s}$ compared with the middle group and of $31 \mathrm{~s}$ compared with the bottom group during laser-run performance. At the same time, in general the top group showed a better hit rate compared with their competitors in the field, which might affect total shooting time [22].

Kim et al. [22] found no significant difference between high- and low-level athletes in total running time, running time in each section, and running speed in the entire laser-run. Any significant inter-group difference demonstrates a meaningful implication in determining performance for high- and low-level athletes. Han et al. [13] found no significant difference between the top $25 \%$ group and the bottom $25 \%$ group in running records, but they showed that converted laser-run scores had significant differences. Therefore, obtaining correct data concerning the records of each event can be an important factor for athlete management. Comprehensive and systematic measurement and analysis of the records of athletes is expected to provide important data for setting training goals and in planning a training level for each event. 
Table 5. Performance during the $\mathrm{CE}^{*}$ and shooting sessions for the top, middle, and bottom third of competitors in the $\mathrm{CE}^{*}$

\begin{tabular}{|c|c|c|c|c|c|c|c|}
\hline \multirow[b]{2}{*}{ Variables } & \multirow[b]{2}{*}{$\begin{array}{c}\text { Total CE } \\
\text { performance(s) }\end{array}$} & \multicolumn{2}{|c|}{ Running performance } & \multicolumn{3}{|c|}{ Shooting performance } & \multirow[b]{2}{*}{ References } \\
\hline & & $\begin{array}{c}\text { Total } \\
\text { running } \\
\text { time(s) }\end{array}$ & $\begin{array}{c}\text { Running } \\
\text { speed } \\
(\mathbf{k m} / \mathbf{h r})\end{array}$ & $\begin{array}{l}\text { Total shooting } \\
\text { time(s) }\end{array}$ & $\begin{array}{c}\text { Total } \\
\text { shooting } \\
\text { accuracy } \\
(\%) \\
\end{array}$ & $\begin{array}{l}\text { Delay per } \\
\text { attemp (s) }\end{array}$ & \\
\hline Top third & $\begin{array}{c}695 \\
( \pm 10)\end{array}$ & $\begin{array}{c}551 \\
( \pm 11)\end{array}$ & $\begin{array}{c}18.2 \\
( \pm 0.4)\end{array}$ & $\begin{array}{c}86 \\
( \pm 16)\end{array}$ & $\begin{array}{c}79 \\
( \pm 13)\end{array}$ & $\begin{array}{c}4.5 \\
( \pm 0.4)\end{array}$ & \multirow{3}{*}{$\begin{array}{c}\text { LeMeur Y et al. } \\
\text { [32] }\end{array}$} \\
\hline Middle third & $\begin{array}{l}714 \\
( \pm 7) \\
\end{array}$ & $\begin{array}{r}549 \\
( \pm 20) \\
\end{array}$ & $\begin{array}{c}18.2 \\
( \pm 0.6) \\
\end{array}$ & $\begin{array}{c}109 \\
( \pm 19) \\
\end{array}$ & $\begin{array}{c}68 \\
( \pm 12) \\
\end{array}$ & $\begin{array}{c}5.0 \\
( \pm 0.7) \\
\end{array}$ & \\
\hline Bottom third & $\begin{array}{c}741 \\
( \pm 25) \\
\end{array}$ & $\begin{array}{r}564 \\
( \pm 11) \\
\end{array}$ & $\begin{array}{c}17.7 \\
( \pm 0.3) \\
\end{array}$ & $\begin{array}{c}117 \\
( \pm 23) \\
\end{array}$ & $\begin{array}{c}64 \\
( \pm 10) \\
\end{array}$ & $\begin{array}{c}5.0 \\
( \pm 0.4) \\
\end{array}$ & \\
\hline $\begin{array}{l}\text { High-level } \\
\text { Low-level }\end{array}$ & - & $\begin{array}{c}676.4 \\
( \pm 7.38) \\
706.7 \\
( \pm 8.6)\end{array}$ & $\begin{array}{c}17,73 \\
( \pm 0.6) \\
17.05 \\
( \pm 0.8)\end{array}$ & $\begin{array}{c}77.5 \\
( \pm 1.87) \\
135.1 \\
( \pm 1.92) \\
\end{array}$ & $\begin{array}{c}71.3 \\
( \pm 11.4) \\
78.5 \\
( \pm 17.7)\end{array}$ & $\begin{array}{c}1.28 \\
( \pm 0.1) \\
1.30 \\
( \pm 0.2)\end{array}$ & $\begin{array}{c}\text { Kim YS et al. } \\
\text { Lim CH et al. } \\
\text { Yoon JR et al. } \\
{[22,34,41]}\end{array}$ \\
\hline $\begin{array}{c}\text { Top 25\% } \\
\text { Bottom 25\% }\end{array}$ & - & $\begin{array}{c}683.53 \\
( \pm 36.42) \\
700.40 \\
( \pm 183.69) \\
\end{array}$ & & & & & $\begin{array}{c}\text { Han DR et al. } \\
{[13]}\end{array}$ \\
\hline \#shooting in CE & & & & $\begin{array}{c}3.35 \text { (male) } \\
3.62(\text { female })\end{array}$ & & & $\begin{array}{c}\text { Park JC } \\
\text { et al. } \\
\text { [38] }\end{array}$ \\
\hline
\end{tabular}

*CE: Combined event (laser-run), (41) \#: shooting time/number of shooting

\section{Conclusions}

There are performance determinants for each event so that athletes can attain the best performance in every sport. The most important principle of training to improve these performance factors is the principle of specificity. To determine the specificity of modern pentathletes, efforts to analyze the factors for performance and measure and analyze the variables cannot be overemphasized. This study aimed to analyze the anthropometric, exercise-physiological, and performance characteristics of elite modern pentathletes; and the findings of a literature review can be summarized as follows.

The anthropometric data for elite modern pentathlon athletes are characterized by medium sight length, muscular skeleton, relatively low \%body fat, and muscular physique.

For exercise-physiological characteristics, because instantaneous heart rate control following rapid running is used as a useful determinant of performance in the recently revised combined event (laser-run), good cardiorespiratory endurance and anaerobic capabilities are essential factors, along with high lactate tolerance.

Almost no research has been conducted on whether the determinants of performance in modern pentathlon are generated from running records in the recently revised laser-run or from the shortened shooting time. Considering that high-level athletes showed statistically better results than low-level athletes in each of total performance time for a laser-run, total running time, transition time, running time in each section, and running speed, as found in the comparison of comprehensive and systematic records from correct data, these results can be used as important data and useful indexes for setting a training goal and in planning a training level for each event.

For the future direction of research for the development of world-class athletes, it is necessary to improve running records and devise various training methods for optimal conditions in transition to pistol shooting on arrival at a pistol shooting site because the recently revised laser-run depends on the running speed and the quick motions and hit rate of pistol shooting.

It is also necessary to develop an effective interval training method for improving anaerobic threshold, cardiorespiratory endurance, and lactate tolerance with the aim of having a competitive edge over world-class athletes.

\section{REFERENCES}

[1] Owen A L., Lago-Peñas C., Dunlop G., Mehdi R., Chtara M., Dellal. A., "Seasonal body composition variation amongst elite European professional soccer players: an approach of talent identification," J Hum Kinet. 2018, pp. 177-84.

[2] Armbruster M., Rist M., Seitfert S., Frommherz S., Weiner C., Mack C., Roth A., Mertz B., Bunzel D., Kruger R., Kulling S., Waltz B., Bub. A., "Metabolite profiles evaluated, according to sex, do not predict resting energy expenditure and lean body mass in healthy non-obese subjects," European journal of nutrition, vol. 58, no. 6, pp. 2207-2217, 2019. DOI: 10.1007/s00394-018-1767-1.

[3] Boone J., Vaeyens R., Steyaert A., Vanden Bossche L., Bourgois J., "Physical fitness of elite Belgian soccer 
players by player position," The Journal of Strength \& Conditioning Research, Vol. 26, no. 8, pp. 2051-2057, 2012. DOI: 10.1519/JSC.0b013e318239f84f.

[4] Buglione A., Lazzer S., Colli R., Introini E., di Prampero P. E., "Energetics of best performances in elite kayakers and canoeists," Med Sci Sports Exerc, vol. 43, no. 5, pp. 87784, 2011. DOI: 10.1249/MSS.0b013e3181fdfdb7.

[5] Coote J., "Recovery of heart rate following intense dynamic exercise," Experimental physiology, vol. 95, no. 3, pp. 431-440, 2010. DOI: 10.1113/expphysiol.2009.0475 48.

[6] Dadswell C., Payton C., Holmes P., Burden. A., "The effect of time constraints and running phases on combined event pistol shooting performance," Journal of sports sciences, vol. 34 , no. 11 , pp. 1044-1050, 2016. DOI: 10.1080/02640414.2015.1088163.

[7] Mon-López D., Zakynthinaki M., Cordente C. A., García-González J., "The relationship between pistol Olympic shooting performance, handgrip and shoulder abduction strength," Journal of human kinetics. vol. 69, pp. 39-46, 2019. DOI: 10.2478/hukin-2019-0009.

[8] Duncan M. J., Woodfield L., al-Nakeeb Y., "Anthropometric and physiological characteristics of junior elite volleyball players," British journal of sports medicine, Vol. 40, no. 7, pp. 649-651, 2006. DOI: 10.1136/bjsm.2005.021998.

[9] Roelofs E., Smith-Ryan A., Trexler E., Hirsch. K, "Seasonal effects on body composition, muscle characteristics, and performance of collegiate swimmers and divers, Journal of athletic training, vol. 52, no. 1, pp. 45-50, 2017. DOI: 10.4085/1062-6050-51.12.26.

[10] Faude O., Meyer T., Rosenberger F., Fries M., Huber G., Kindermann W., "Physiological characteristics of badminton match play," European journal of applied physiology, vol. 100, no. 4, pp. 479-485, 2007. DOI: 10.1007/s00421-007-0441-8.

[11] Wilson G., Sparks S. A., Drust B., Morton J., Close G., "Assessment of energy expenditure in elite jockeys during simulated race riding and a working day: implications for making weight," Applied physiology, nutrition, and metabolism, vol. 38, no. 4, pp. 415-420, 2013. DOI: 10.1139/apnm-2012-0269.

[12] Gutierrez-Davila M., Rojas F., Antonio R., Navarro E, "Response timing in the lunge and target change in elite versus medium-level fencers," European Journal of Sport Science, vol. 13, no. 4, pp. 364-374, 2013. DOI: 10.1080/17461391.2011.635704.

[13] Han D. R., Choi H. J., "Comparison of performances before and after the rule changes in the modern pentathlon," Korean J. Phys. Educ, vol 55, no. 4, pp. 541-550, 2016. URL: https://www.dbpia.co.kr/Journal/articleDetail?nodeI $\mathrm{d}=$ NODE09112757.

[14] Hitchens P., Blizzard L., Jones G., Day L., Fell J., “Are physiological attributes of jockeys predictors of falls? A pilot study," BMJ open, vol. 1, no. 1, pp. e000142, 2011. DOI: 10.1136/bmjopen-2011-000142.

[15] Hoffmann B., Flatt A., Virgilio Silva L. E., Marcelo S. M., Baranowski R., Dziedzic E., et al. "A pilot study of the reliability and agreement of heart rate, respiratory rate and short-term heart rate variability in elite modern pentathlon athletes," Diagnostics, vol. 10, no. 10, pp. 1-22, 2020. DOI: 10.3390/diagnostics10100833.

[16] Ignjatovic A., Radovanovic D., Stankovic R., Markovic Z., Kocic J., "Influence of resistance training on cardiorespiratory endurance and muscle power and strength in young athletes," Acta Physiologica Hungarica, Vol. 98, no. 3, pp. 305-312, 2011. DOI 10.1556/aphysiol.98.2011.3.7.

[17] Sterkowicz-Przybycień K., "Body composition and somatotype of the elite of Polish fencers," Collegium Antropologicum, vol. 33, no. 3, pp. 765-72, 2009. URL: https://hrcak.srce.hr/41816.

[18] Ghloum K., Hajji S., "Comparison of diet consumption, body composition and lipoprotein lipid values of Kuwaiti fencing players with international norms," Journal of the International Society of Sports Nutrition, vol. 8, no. 1, pp. 1-9, 2011. DOI: 10.1186/1550-2783-8-13.

[19] Kim K. J., "Comparisons of aerobic capacity and exercise-induced responses of blood lactate and ammonia concentration according to the different exercise types between modern pentathlon and taekwondo athletes," KAHPERD, Vol. 40, no. 1, pp. 481-489, 2001. URL: https://kiss.kstudy.com/thesis/thesis-view.asp?key=373153 1.

[20] Kim D. H., Kim S. J., Choi J. H., "Effects of reduced training on performance of swimming, running and POMS in modern pentathlonists," The Korean Journal of Sport, vol. 13, no. 13, pp. 79-86, 2015. URL: https://www.earticle.net/Article/A241313.

[21] Kim H. S., Pyo J. H., Cho I. H., Lee J. S., Him C. K., "Comparisons of maximal swimming performance and physiological variables among elite competitive swimmers, modern pentathletes and water polo players during recovery," Exercise Science, Vol. 12, no. 4, pp. 715-726, 2003. URL: https://kiss.kstudy.com/thesis/thesis-view.asp? key $=2119961$.

[22] Kim Y. S., Yoon J. R., Hur S., "Comparison of new combined event performance by performance level in modern pentathlon athletes," Exercise Science, vol. 25, no. 4, pp. 282-287, 2016. URL: https://kiss.kstudy.com/thesis/t hesis-view.asp?key=3484264.

[23] Kim M. S., Kim H. J., Kang T. Y., An C. S., "A policy recommendation for the development of the modern pentathlon," Journal of Korean Society of Sport Policy, vol. 16, no. 1, pp. 103-122, 2018. URL: https://kiss.kstudy.com /thesis/thesis-view.asp?key=3577414.

[24] Kim S. Y., Cho J. H., Lee J. H., Jung J. H., Changes in body composition, energy metabolism, and appetite-regulating hormones in Korean professional female ballet dancers before and after ballet performance. Journal of Dance Medicine \& Science, vol. 23, no. 4, pp. 173-180, 2019. DOI: 10.12678/1089-313X.23.4.173.

[25] Korea Institute of Sports Science (KOR). "Textbook for Coahingboo Leader of Korean National Modern Pentathlon Federation," 2010.

[26] Kovacs M. S., "Tennis physiology: training the competitive athlete," Sports medicine, vol. 37, no. 3, pp. 189-198, 2007. DOI: 10.2165/00007256-200737030-0000 1. 
[27] Kusy K, Zielinski J., "Aerobic capacity in speed-power athletes aged 20-90 years vs endurance runners and untrained participants," Scandinavian journal of medicine \& science in sports, vol. 24, no. 1, pp. 68-79, 2014. DOI: 10.1111/j.1600-0838.2012.01496.x.

[28] Lakie M., "The influence of muscle tremor on shooting performance," The influence of muscle tremor on shooting performance, vol. 95 , no. 3, pp. 441-450, 2010. DOI: 10.1113/expphysiol.2009.047555.

[29] Lee C. H., Jang K. T., "Short-tern plyometric tranining on $1,000 \mathrm{~m}$ running performance and explosive power in modern pentathlon athletes," The Korea Journal of Sport, vol. 11, no. 2, pp. 195-203, 2013. URL: https://www.earticle.net/Article/A200534.

[30] Lee S. I., An C. S., "The comparative study of shooting, swimming, track and field between world record and national record in modern pentathlon players," The Korea Journal of Sport, vol. 10, no.1, pp.157-163, 2012. URL: https://scholarworks.bwise.kr/cau/handle/2019.sw.cau/461 56.

[31] Le Meur Y., Hausswirth C., Baup Y., Dorel S., Guyomarch J. P., Roudaut C., "Physiological demand and pacing strategy during the new combined event in elite pentathletes," European journal of applied physiology, vol. 112 , no. 7 , pp. $2583-2593,2012$. DOI: $10.1007 / \mathrm{s} 00421-01$ $1-2235-2$.

[32] Le Meur Y., Hausswirth C., Abbiss C., Baup Y., Dorel S., "Performance factors in the new combined event of modern pentathlon," Journal of sports sciences, vol. 28, no. 10, pp.1111-1116, 2010. URL: 10.1080/02640414.2010.49 7816.

[33] Alves Coutinho L. A., Melo Porto C. P., Rocha Pierucci A. P. T. R., "Critical evaluation of food intake and energy balance in young modern pentathlon athletes: a cross-sectional study," Journal of sports sciences, vol. 28, no. 10, pp. 1111-1116, 2016. DOI: 10.1080/02640414.2010.497816.

[34] Lim C. H., Yoon J. R., Jeong C. S., Kim Y. S., “An analysis of the performance determinants of modern pentathlon athletes in laser-run, a newly combined event in modern pentathlon," Exercise Science, vol. 27, no. 1, pp. 62-70, 2018. DOI: /10.15857/ksep.2018.27.1.62.

[35] Loureiro L. L., Fonseca S., de Oliveira e1dos Castro N. G. C., dos Passos R. B., Melo Porto C. P., Rocha Pierucci A. P. T. R., "Basal metabolic rate of adolescent modern pentathlon athletes: agreement between indirect calorimetry and predictive equations and the correlation with body parameters," PLOS ONE. vol. 10, no. 11, pp. 1-12, 2015. DOI: 10.1371/journal.pone.0142859.

[36] Luchsinger H., Talsnes R. K., Kocbach J., Sandbakk Ø., "Analysis of a biathlon sprint competition and associated laboratory determinants of performance," Frontiers in Sports and Active Living, vol. 1, no. 60, 2019. DOI: 10.3389/fspor.2019.00060.

[37] Molla R. Y., Sadeghi H., Bayati A., "The comparison of static balance among the elite shooters of the Iranian national rifle and pistol shooting team with an emphasis on principle anthropometric indicators," Journal of Clinical Physiotherapy Research, vol. 3, no. 3, pp. 105-112, 2018. DOI: $10.22037 /$ English.v3i3.21496.

[38] Park J. C., Lee S. H., "The analysis of game outcomes based on UIPM shooting match data in the modern pentathlon," Journal of Digital Convergence, vol. 18, no. 6, pp. 523-529, 2020. DOI: JDC.2020.18.6.523.

[39] Cech P., Maly T., Mala L., Zahalka F., "Body composition of elite youth pentathletes and its gender differences," Sport Sci, vol. 6, no. 3, pp. 29-35, 2013. URL: https://sposci.com/PDFS/BR0602/SVEE/04\%20CL\%2005 $\% 20$ PC.pdf.

[40] Yoon J. R., Kim Y. S., "Study of VE, $\mathrm{VO}_{2} \max , \mathrm{AT}-\% \mathrm{VO}_{2}$ $\max , \mathrm{VO}_{2} / \mathrm{HR}$ in modern pentathlon athletes of KNSU," The Korea Journal of Sport, vol. 16, no. 1, pp. 653-662, 2018. ULR: earticle.net/Article/A325253.

[41] Yoon J. R., Hur S. "Analysis of physiological parameters for new combined event in modern pentathletes," The Official Journal of the Korean Academy of Kinesiology, vol. 19, no. 1, pp. 11-16, 2017. DOI: 10.15758/jkak.2017.1 9.1.11.

[42] Yoon J. R., "Diagnosis and evaluation of personalized physical fitness of pentathlon athletes," Diagnostics," The Korea Journal of Sport, vol. 17, no. 2, pp. 1257-1265, 2019. URL: https://www.earticle.net/Article/A355826.

[43] Yoon J. R., "Physiological profiles of elite senior wrestlers," Sports Medicine, vol. 32, no. 4, pp. 225-233, 2002. DOI: $10.2165 / 00007256-200232040-00002$.

[44] Zinner C., Sperlich B., Wahl P., Mester J., "Classification of selected cardiopulmonary variables of elite athletes of different age, gender, and disciplines during incremental exercise testing," Springerplus, vol. 4, no. 1, pp. 1-9, 2015. DOI: $10.1186 / 2052-1847-7-5$. 